\title{
Thermoregulation mode, substrate temperature and camouflage efficiency affecting defensive behavior of lizards in Amazonia
}

\author{
Erika SOUZA ${ }^{1,2^{*}} \oplus$, Ana COELHO ${ }^{1,2}$, Alfredo P. SANTOS-JR ${ }^{1,2}$, Ricardo Alexandre KAWASHITA- \\ RIBEIRO $^{1,2}$, Rafael de FRAGA ${ }^{2,3}$ \\ Universidade Federal do Oeste do Pará, Programa de Pós-Graduação em Biodiversidade, Rua Vera Paz, s/n, CEP 68040-470, Santarém, Pará, Brazil \\ 2 Universidade Federal do Oeste do Pará, Laboratório de Ecologia e Comportamento Animal, Rua Vera Paz, s/n, CEP 68040-470, Santarém, Pará, Brazil \\ Universidade Federal do Oeste do Pará, Programa de Pós-Graduação em Recursos Naturais da Amazônia, Av. Mendonça Furtado 2946, CEP 68040-050 \\ Santarém, Pará, Brazil \\ * Corresponding author: e.sansouza@gmail.com; —D https://orcid.org/0000-0002-6975-2345
}

\begin{abstract}
In ectotherms, defensive responses to predators usually depend on cost-benefit relationships between death risk and the energy required to flee. In this study we investigate Amazonian lizards to test the hypothesis that the minimum predator approach distance (PAD) is influenced by temperature and camouflage. We test the hypothesis that PAD estimated for species with different thermoregulation modes respond differently to temperature and camouflage. We sampled 35 lizards of a heliotherm and a non-heliotherm species, for which we simulated a terrestrial visually oriented predator. Using a fixed-effects linear model, temperature positively affected PAD estimates, but the camouflage did not contribute to the model. Using a mixed linear model assuming thermoregulation mode as a random factor, camouflage negatively affected PAD estimates, independently of temperature. Our findings suggest that high exposure to predators in open habitats may be compensated by rapid fleeing optimized by high temperatures, and low fleeing performance, usually caused by relatively low temperatures in shaded habitats, may be compensated by camouflage. However, identifying the best PAD predictor greatly depended on accounting for thermoregulation mode in hypothesis testing, although the results obtained by both fixed and mixed-effects models may be relevant for conservation.
\end{abstract}

KEYWORDS: Cnemidophorus lemniscatus, escape, Gonatodes humeralis, heliotherm, non-heliotherm, predation pressure

\section{Modo de termorregulação, temperatura do substrato e eficiência da camuflagem afetam o comportamento defensivo de lagartos na Amazônia}

\section{RESUMO}

Em ectotérmicos, respostas defensivas a predadores geralmente dependem de relações de custo-benefício entre risco de morte e a energia necessária para fugir. Neste estudo, investigamos lagartos na Amazônia para testar a hipótese de que a distância mínima de aproximação de predadores (DAP) é influenciada pela temperatura e camuflagem. Nós testamos a hipótese de que estimativas de DAP para espécies com diferentes modos de termorregulação respondem diferentemente à temperatura e camuflagem. Nós amostramos 35 lagartos de uma espécie heliotérmica e uma não heliotérmica, para as quais simulamos um predador terrestre visualmente orientado. Usando um modelo linear de efeitos fixos, a temperatura afetou positivamente as estimativas de DAP, mas a camuflagem náo contribuiu para o modelo. Usando um modelo linear de efeitos mistos, a camuflagem afetou negativamente as estimativas de DAP, independentemente de temperatura. Nossos resultados sugerem que alta exposição a predadores em hábitats abertos pode ser compensada por fuga rápida otimizada por altas temperaturas, e o baixo desempenho de fuga, usualmente causado por temperaturas relativamente mais baixas em habitats sombreados, pode ser compensado pela camuflagem. No entanto, a identificação do melhor preditor de DAP dependeu muito de considerar o modo de termorregulação nos testes de hipóteses, apesar de que os resultados obtidos por ambos os modelos de efeitos fixos e mistos podem ser relevantes para conservação.

PALAVRAS-CHAVE: Cnemidophorus lemniscatus, fuga, Gonatodes humeralis, heliotérmico, não-heliotérmico, pressão de predação 


\section{INTRODUCTION}

Mortality rates are widely influenced by the distance to which prey allows the predator to approach, which in turn can be determined by cost-benefit relationships between death risk and the energy cost to flee (Ydenberg and Dill 1986). Regarding lizards occupying warm habitats, temperatureinduced metabolic and physiological processes are expected to favor rapid fleeing reactions into shelters (Ventura et al. 2016). In the absence of shelters available, lizards can thermoregulate to increase their chance of fleeing, despite the energy cost and temporary (while basking) increase of exposure to predators (Basson et al. 2016). This may be explained by temperaturedependent sprint speed (Zamora-Camacho et al. 2015), by which low temperatures are expected to cause inadequate fitness for successive quick runs (Basson et al. 2016), and freezing should be a better option than fleeing in the absence of defensive-aggressive behavior repertoire (Crowley and Pietruszka 1983; Cooper and Pérez-Mellado 2004; Samia et al. 2015). Therefore, lizards that are typical of shaded habitats (non-heliotherms) should be subjected to higher selective pressure for camouflage efficiency than those typical of sunny habitats (heliotherms), and thermoregulation mode seems to be a major factor influencing responses to predators (Seebacher and Franklin 2005).

The effects of temperature on ectotherms (e.g. metabolic activity, fitness) have been described as a continuous gradient from passive thermoconformity to metabolic regulation at approximate homeostasis (Fitzgerald et al. 2003; Seebacher and Shine 2004). Proportions of this gradient that are occupied by a species depend on a combination of habitat thermal quality, cost-benefit of thermoregulation, and behavioral repertoires related to the optimization of heatsource use (Huey and Slatkin 1976; De Lanuza et al. 2016). Wide regions of the gradient are usually occupied by thermal generalists (Templeton 1970), and the extremes are occupied by specialists with more narrow thermal ranges, related to the concept of heliotherms and non-heliotherms, a common classification for lizards. Heliotherms shuttle between sunny and shaded habitats, which continuously reverses heat flux to keep body temperatures within a narrow optimal range (Templeton 1970). This is relevant for performance and fitness optimization, to avoid overly long exposure to cold or overheating, and is regulated by the cost-benefit balance of energy expenditure in searching for heat sources (Gontijo et al. 2018), although the search time may be constricted by the increased exposure to predators (Pianka and Pianka 1970). In contrast, non-heliotherms are nocturnal or occupy shaded habitats where direct sunlight rarely penetrates. For these animals, the benefits of thermoregulation hardly compensate the energy cost of searching for heat sources, so they tend to select habitats regardless of thermal quality (Fitzgerald $e t$ al. 2003).
Lizards may be great models to investigate factors affecting defensive behavior and camouflage, because their metabolism is dependent on temperature, and a number of species evolved cryptic body colors (Heatwole 1968; Ydenberg and Dill 1986; Martín and Lopez 1995; Cooper and PérezMellado 2004). In general, thermoregulatory species (e.g. heliotherms) are expected to have adequate fitness to rapidly flee as soon as they detect a predator, while species more prone to thermoconformism (e.g. non-heliotherms) tend to allow predators to approach at closer distances (Greene 1988). For the latter, camouflage efficiency is thought as an alternative defense mechanism to high fleeing capability. Therefore, the minimum predator approach distance (PAD) may depend on factors such as predator approach speed and body size, lizard body temperature and the efficiency of their camouflage (Heatwole 1968). Since the fitness required for escape is dependent on nutrient input, PAD may also depend on the relationship between food availability and competition (Pérez-Mellado 1998).

In this study we sampled two lizard species with different thermoregulation modes: the heliothermic Cnemidophorus lemniscatus (Teiidae), and the non-heliothermic Gonatodes humeralis (Sphaerodactylidae), to investigate the influence of substrate temperature and camouflage efficiency on PAD estimates. We hypothesized that heliothermic lizards would show escape reactions at greater distances from the simulated predator than non-heliothermic lizards. This hypothesis was based on the general premise that heliotherms benefit from high body temperatures that enable a quick fleeing reaction, resulting in a stronger effect of temperature on PAD compared to non-heliotherms. Conversely, based on the assumption that non-heliothermic lizards are usually active at relatively lower temperatures compared to heliotherms (Vitt et al. 2008), we hypothesized that the lizards would allow a simulated predator to get closer, resulting in PAD estimates more related to camouflage efficiency than temperature.

\section{MATERIAL AND METHODS}

\section{Study area}

We collected data in the area of the reservoir of the Curuá-Una Hydroelectric Powerplant, in the municipality of Santarém, western state of Pará, Brazil (centroid coordinates $02^{\circ} 49^{\prime} 23^{\prime \prime}$ S, 54 $17^{\prime} 33^{\prime \prime W}$ ) (Figure 1). The annual average precipitation in the region over the past five years is 2150 $\mathrm{mm}$ (INMET 2020), and the rainfall is highly seasonal, with a dry season from July to November, and a rainy season from December to June.

\section{Target species}

We constructed approach distance models with data from two species of diurnal lizards that occur in the Brazilian Amazon. Cnemidophorus lemniscatus (Teiidae) is a terrestrial, 


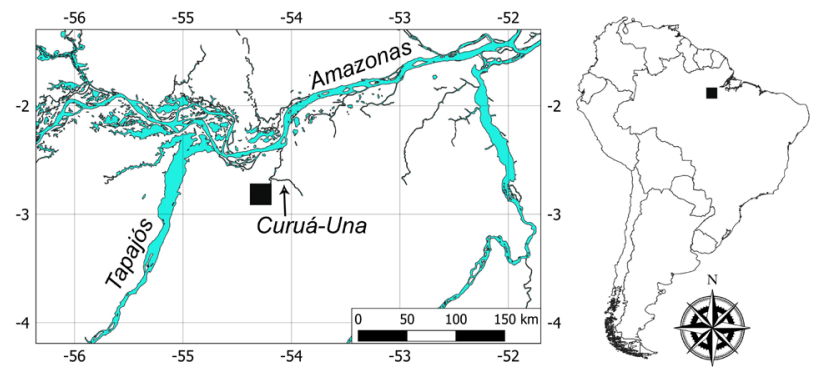

Figure 1. Study area (black square) for lizard sampling in the vicinity of the Curuá-Una hydroletric powerplant, Santarém, Pará, Brazil. This figure is in color in the electronic version.

active forager, endemic to the eastern Amazon (Magnusson et al. 1985). This species is usually classified as heliothermic because its active thermoregulatory behavior generates body temperatures well above the air temperature, although this relationship may be weakened under air temperatures above $30{ }^{\circ} \mathrm{C}$ (Magnusson 1993). Gonatodes humeralis (Sphaerodactylidae) is an arboreal gecko, widely distributed throughout the Amazon basin, gallery forests in central Brazil, and Trinidad and Tobago (Vitt et al. 2008). This species is usually classified as non-heliothermic because it spends little time under direct sunlight and moves in sunny areas only for short distances. Therefore, its body temperatures tend to be close to the air temperature (Vitt et al. 1997).

\section{Sampling design}

We simulated a terrestrial visually oriented predator in habitats in which the studied species occur naturally, by slowly approaching lizards in open and forested areas. During the approach, we photographed lizards using a Nikon Coolpix P500 ${ }^{\mathrm{TM}}$ camera, equipped with a Nikkor ED crystal lens (optical zoom 36x), with automatic definitions of exposure compensation and objective lens aperture. We took the photos from safe enough distances so that the lizards would not leave the sites where they were first spotted. The distances of the photos were usually greater for $C$. lemniscatus (average $3 \mathrm{~m}$ ) compared to G. humeralis (average $1 \mathrm{~m}$ ). However, this approach was effective in quantifying the camouflage efficiency at the exact spot where the lizards showed defensive responses. We measured PAD by the straight line between the observer and the spot at which the lizard escaped. This method has been shown to be efficient to study the defensive behavior in lizards, as the escape response is generally easily recognized (e.g. Cooper and Pérez-Mellado 2004). We were able to easily distinguish foraging or resting behavior from defensive response. Cnemidophorus lemniscatus foraged with its head down, alternating short runs with slow movements while searching the ground, and defended itself with its head up and long fast runs. Gonatodes humeralis is an ambush forager and spends most of the time stationary (Vitt et al. 1997). Therefore, it was usually motionless, and moved only with the approach of the observer.
We collected data continuously between 22 and 24 June 2018. We distributed the surveys in daily sections of four hours (11:00 h to 15:00 h). In each section we alternated sampling at one-hour intervals in open areas, where all $C$. lemniscatus were sampled, and forested areas where we sampled all $G$. humeralis. Three observers conducted sampling sections simultaneously, totalling 36 observer-hours of sampling effort equally (18 hours each) divided between open and forested areas. The same observer (senior author) simulated a predator throughout the study, wearing the same outfit in all sampling sections. This approach was useful to minimize potential effects of body size and clothing colors on lizard responses.

\section{Independent variables}

We measured substrate temperature at the time of the fleeing reaction using a thermometer positioned with the metal tip in contact with the substrate at the spot where we first saw each lizard. The average substrate temperature was $30.7^{\circ} \mathrm{C}(26.9-36.6$, standard error $=0.37, \mathrm{~N}=35)$. We also measured air temperature and relative humidity, but these variables were highly correlated with substrate temperature (Pearson $r=0.82$ and -0.77 , respectively), so we did not use them in the analysis.

To quantify camouflage efficiency, we imported the photos of each individual into the software ImageJ, in which we isolated the lizards from the background. We standardized the photos by size $(40 \mathrm{~cm}$ in width, $30 \mathrm{~cm}$ in height), resolution (300 dpi) and proportions of lizard and background (approximately 50\% each). We disregarded leaves in the foreground, which were not part of the background. We obtained average numbers of red, green, and blue (RGB) pixels, separately for lizards and background. We calculated the RGB differences between lizards and background by background - lizards, and squared the results to avoid negative values. We used a Principal Component Analysis (PCA) to summarize RGB differences in a single dimension. The first axis of the PCA captured $90 \%$ of the original variance in RGB, so we used it as an univariate representation of camouflage efficiency. This approach is analogous to what the patternize R-package does (Belleghem et al. 2018), with the main difference that we obtained average RGB values from an overview of lizard and background, rather than predefined landmarks. Since we were interested in simulating the overview of predators scanning the environment for lizards, we assumed that a simplified version of PCA-based color quantification is efficient to test our hypotheses.

\section{Data analysis}

We used a non-parametric Kruskal-Wallis test to compare PAD estimates between heliothermic and non-heliothermic lizards. To test whether substrate temperature (TEM) and camouflage (CAF) influence PAD estimates, we used multiple linear regression, given by $P A D=a+b_{I}(T E M)+b_{2}(C A F)$. 
The independent variables were weakly correlated (Pearson $r=-0.05)$, and the residuals did not differ from a normal distribution (Shapiro-Wilk, $\mathrm{p}=0.98$ ). All analyses were performed in R (R Development Core Team 2020), and we used the car package (Fox and Weisberg 2011) to plot partials from the multiple linear regression.

In addition to the fixed-effects multiple linear regression, we estimated the effects of temperature and camouflage on PAD estimates conditioned by the thermoregulation mode. We applied a mixed linear model (Laird and Ward 1982) using $\mathrm{PAD}$ as a response variable, temperature and camouflage as predictor variables and thermoregulation mode as a random factor. This approach was useful to account for any effect of thermoregulation mode on lizard defensive responses to temperature and camouflage while saving degrees of freedom, since splitting the data by thermoregulation mode resulted in relatively small sample sizes. We scaled the predictor variables to obtain averages of approximately zero and standard deviations of approximately 1 and implemented the mixed model in the lme4 R-package (Bates et al. 2015). To obtain P-values we used a Kenward-Roger test, which was suitable for the relatively small sample-size (Kenward and Roger 1997). The residuals from the mixed model did not differ from a theoretical normal distribution (Shapiro-Wilk, $\mathrm{p}=0.15$ ).

\section{RESULTS}

We sampled 35 adult lizards, of which 17 were $C$. lemniscatus and 18 were $G$. humeralis. Backgrounds on which we found $C$. lemniscatus were sandy roads, natural and artificial rocks, and grassy vegetation, while $G$. humeralis was usually on tree trunks, and rarely on natural rocks within shaded areas.

The PAD estimates were significantly higher in $C$. lemniscatus (Figure 2a) compared to G. humeralis (KruskalWallis, $\left.\mathrm{X}^{2}=20.75, \mathrm{P}<0.0001\right)$, which was consistently captured by the fixed-effects multiple linear model (Figure $2 \mathrm{~b})$, showing that PAD is not random $\left(\mathrm{r}^{2}=0.52, \mathrm{p}<0.001\right.$, standard error $=0.81$ ), but positively related to substrate temperature $(\mathrm{t}=5.84, \mathrm{p}<0.001)$. Camouflage efficiency (Figure 2c) did not contribute significantly to the model (p $=0.21$ ).

The mixed linear model captured $80 \%$ of the variance in PAD conditioned by the thermoregulation mode (variance for thermoregulation mode / total variance), and showed a negative effect of camouflage on PAD (slope $=-0.35, \mathrm{p}=$ 0.009). The predicted PAD response to camouflage (Figure $2 \mathrm{~d}$ ) was apparently better fitted to $G$. humeralis than $C$. lemniscatus (variance for camouflage of $G$. humeralis $=1.10, C$. lemniscatus $=0.28$, overall $=0.71)$. Temperature did not significantly affect

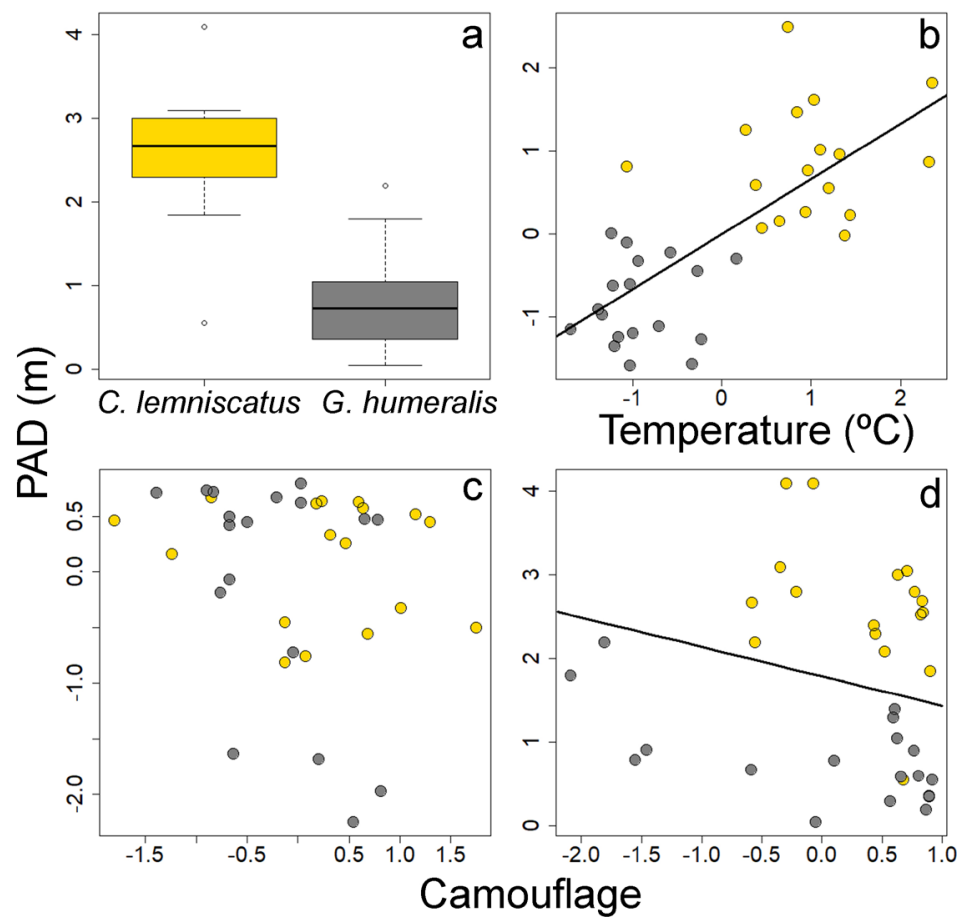

Figure 2. General effects of substrate temperature and camouflage (summarized differences in RGB values between lizards and backgrounds) of two lizard species in Amazonia on estimates of minimum predator approach distance (PAD). In all the graphs, the yellow color denotes the heliotherm Cnemidophorus lemniscatus and the gray color the non-heliotherm Gonatodes humeralis. a) Boxplot showing mean differences in PAD between C. lemniscatus and G. humeralis. Horizontal lines in bold represent medians, the boxes delimit first and third quartiles, and the whiskers are amplitudes; b) Partials from a multiple linear regression showing the effects of temperature on PAD estimates; $c$ ) Partials from a multiple linear regression showing the effects of camouflage on PAD estimates; d) Relationship between camouflage and PAD predicted by a mixed linear model configured with thermoregulation mode as a random factor. This figure is in color in the electronic version. 
PAD estimates conditioned by thermoregulation mode $(\mathrm{p}=$ 0.65 ). Table 1 summarizes the outputs of the mixed-effects linear model.

\section{DISCUSSION}

Our data showed that substrate temperature is a determining factor for the fleeing reactions of the studied lizards, when the model arbitrarily neglected thermoregulation mode. Temperature is a limiting abiotic factor for the metabolism of ectotherms (Huey and Kingsolver 1989; Vitt and Caldwell 2009), and determines the rate at which lizards may respond to predators (Heatwole 1968). However, this relationship is highly dependent on the thermoregulation mode, considering differences in the PAD estimates between C. lemniscatus and $G$. humeralis and the results from the mixed-effects linear model.

The fixed-effects linear model indicated that high temperatures caused high PAD values, regardless of camouflage efficiency. This finding was particularly evident for the heliothermic C. lemniscatus, and may be associated with high predator exposure and low availability of refuges in open habitats (Heatwole 1968; Martín and López 1999; Ventura et al. 2016). Defensive behavior in heliotherms is highly associated with temperature, which may cause a variety of stereotyped reactions optimized by accelerated metabolisms (Arnold 1988; Greene 1988). Additionally, lizards living in open areas are more exposed to avian predators, which should have higher success rates by differentiating lizards from the substrate, due to well-developed vision (Robinson 1994). According to our mixed-effects linear model, camouflage efficiency may be an alternative defensive mechanism, especially in the absence of nearby shelters. Therefore, costbenefit relationships between death risk and the energy cost of escape should favor high-speed fleeing (Ventura et al. 2016), as in heliothermic rock-dwelling specialist lizards (Rocha and Bergallo 1990), or alternative defensive decisions (e.g. sheltering in matching backgrounds) mediated by the availability of shelters (Salido and Vicente 2019).

Relatively low temperatures and PAD values indicated that $G$. humeralis is unlikely to benefit from high temperatures to perform long, fast escape runs. In fact, non-heliothermic lizards typically occupy shaded and relatively cold habitats that favor camouflage efficiency in risk-energy relationships, and well-camouflaged lizards allow approach distances that are shorter than one meter (Heatwole 1968; Howland et al. 1990; Cooper 2008). Cryptic body color compensates the escaping ability limited by metabolism, as well as the need to flee into shelters with unfavorable temperature (Martín and López 1999). Alternatively, this finding possibly supports one of the premises of the optimal escape theory, which predicts that a prey allows a close approaching of predators in the presence of food, so that it does not miss an opportunity
Table 1. Summary of results of the mixed linear model used to test the influence of substrate temperature and camouflage efficiency conditioned by thermoregulation mode (heliothermic and non-heliothermic) on the minimum predator approach distance of Cnemidophorus lemniscatus and Gonatodes humeralis. SD = standard deviation. P-values were obtained with the KenwardRoger test.

\begin{tabular}{|c|c|c|c|c|}
\hline Random effects & Variance & SD & & \\
\hline $\begin{array}{l}\text { Thermoregulation } \\
\text { (intercept) }\end{array}$ & 1.590 & 1.261 & & \\
\hline Residual & 0.411 & 0.644 & & \\
\hline Fixed effects & Estimate & SE & t-value & $p$-value \\
\hline Intercept & 1.795 & 0.898 & 1.998 & \\
\hline Temperature & 0.08 & 0.188 & 0.449 & 0.65 \\
\hline Camouflage & -0.35 & 0.135 & -2.607 & 0.009 \\
\hline
\end{tabular}

to feed (Ydenberg and Dill 1986). This behavior is even more pronounced in high-density populations, in which intraspecific competition for food is often more intense (PerézMellado 1998). Additional data on population density and food availability are needed to explicitly test this hypothesis.

Although predicting the escape behavior of lizards was highly dependent on the statistical approach, assuming both temperature and camouflage as predictors of PAD has relevant implications for ecology and conservation. This is important because our study area is within a landscape strongly threatened by deforestation and expansion of urban and agricultural areas. Forest fragmentation increases environmental temperature (Murcia 1995), while reducing the availability of shaded shelters, forcing lizards to travel longer distances to thermoregulate or escape from predators (Cooper and Pérez-Mellado 2004). Additionally, increased sunlight by deforestation may change the background color, reducing camouflage efficiency (Delhey and Peters 2016). Both scenarios converge to increase exposure to predators, since variables that directly affect the defensive behavior of lizards have been anthropogenically changed. Therefore, it is widely expected that forest fragmentation is increasing predation pressure on lizards in the study area, although this hypothesis has not yet been explicitly tested.

\section{CONCLUSIONS}

Overall, our study showed that identifying the best predictor of defensive responses in lizards greatly depends on accounting for thermoregulation modes in hypothesis testing. By neglecting thermoregulation mode, one could conclude that metabolism accelerated by high temperatures favors long escape runs from distances safe enough so that most terrestrial predators could not reach the lizard. This is a particularly relevant finding in open and warm tropical habitats, where lizards benefit from muscular bursts to 
avoid predators, and camouflage efficiency apparently plays a minor role in defense. However, conditioning defensive responses by thermoregulation mode revealed that bettercamouflaged lizards tend to allow predators to come closer. This finding might be especially relevant in closed and shaded habitats, where lizards benefit from cryptic body colors to avoid excessive energy expenditure, cool refuges, or loss of opportunities to feed (Vitt and Caldwell 2009). Future studies should focus on greater species diversity, functional traits (e.g. foraging mode, sexual maturity and reproductive cycle stage), and simulations of different predation strategies (e.g. Ventura et al. 2016).

\section{ACKNOWLEDGMENTS}

We thank Programa de Pós-graduação em Biodiversidade, Universidade Federal do Oeste do Pará for the logistical support. Coordenação de Aperfeiçoamento de Pessoal de Nível Superior (CAPES) provided a master's scholarship to ES and $\mathrm{AC}$, and a postdoc grant to RF.

\section{REFERENCES}

Arnold, E.N. 1988. Caudal autotomy as a defense. In: Gans, C.; Huey, R.B. (Ed.). Biology of the Reptilia. Ecology B. Defense and Life History. Alan R. Liss, New York. p.235-273.

Basson, C.H.; Levy, O.; Angilletta-Jr, M.J.; Clusella-Trullas, S. 2016. Lizards paid a greater opportunity cost to thermoregulate in a less heterogeneous environment. Functional Ecology, 31: 856-865.

Bates, D.; Maechler, M.; Bolker, B.; Walker, S. 2015. Fitting linear mixed-effects models using lme4. Journal of Statistical Software, 67: 1-48.

Belleghem, S.M.V.; Papa, R.; Ortiz-Zuazaga, H.; Hendrickx, F.; Jiggins, C.D.; McMillan, W.O.; Counterman, B.A. 2018. patternize: an R package for quantifying colour pattern variation. Methods in Ecology and Evolution, 9: 390-398.

Cooper, W.E. 2008. Strong artifactual effect of starting distance on flight initiation distance in the actively foraging lizard Aspidoscelis exsanguis. Herpetologica, 64: 200-206.

Cooper, W.E.; Pérez-Mellado, V. 2004. Tradeoffs between escape behavior and foraging opportunity by the baleartic lizard (Podarcis lilfordi). Herpetologica, 60: 321-324.

Crowley, S.R.; Pietruszka, R.D. 1983. Aggressiveness and vocalization in the Leopard Lizard (Gambelia wislizennii): the influence of temperature. Animal Behavior, 31: 1055-1060.

De Lanuza, G.P.; Carretero, M.A.; Font, E. 2016. Thermal dependence of signalling: do polymorphic wall lizards compensate for morph-specific differences in conspicuousness? Behavioral Ecology Sociobiology, 70: 1151-1159.

Delhey, K.; Peters, A. 2016. Conservation implications of anthropogenic impacts on visual communication and camouflage. Conservation Biology, 31: 30-39.

Fitzgerald, M.; Shine, R.; Lemckert, F. 2003. A reluctant heliotherm: thermal ecology of the arboreal snake Hoplocercus stephensii
(Elapidae) in dense forest. Journal of Thermal Biology, 28: 515524.

Fox, J.; Weisberg, S. 2011. An $\{R\}$ companion to applied regression, 3rd ed. Thousand Oaks, Sage, 571p.

Gontijo, A.S.B.; Garcia, C.S.; Righi, A.F.; Galdino, C.A.B. 2018. To warm on the rocks, to cool in the wind: Thermal relations of a small-sized lizard from a mountain environment. Journal of Thermal Biology, 76: 52-57.

Greene, H.W. 1988. Antipredator mechanisms in reptiles. In: Gans, C.; Huey, R.B. (Ed.). Biology of the Reptilia. Alan R. Liss, New York, p.1-55.

Heatwole, H. 1968. Relationship of escape behavior and camouflage in Anoline lizards. Copeia, 1: 109-113.

Howland, J.M.; Vitt, L.J.; Lopez, P.T. 1990. Life on the edge: the ecology and life history of the tropidurine iguanid lizard Uranoscodon superciliosum. Canadian Journal Zoology, 68: 1366-1373.

Huey, R.B.; Slatkin, M. 1976. Costs and benefits of lizard thermoregulation. The Quartelry Review Biology, 51: 363-384.

Huey, R.B.; Kingsolver, J.G. 1989. Evolution of thermal sensitivity of ectotherm performance. Trends in Ecology \& Evolution, 4: 131-135.

INMET. 2020. Instituto Nacional de Meteorologia.Departamento Nacional de Meteorologia. (http://portal.inmet.gov.br/). Acessed on 12 Aug 2020.

Kenward, M.G.; Roger, J.H. 1997. Small sample inference for fixed effects from restricted maximum likelihood. Biometrics, 53: 983-997.

Laird, N.M.; Ware, J.H. 1982. Random-effects models for longitudinal data. Biometrics, 38: 963-974.

Magnusson, W.E.; Paiva, L.J.; Rocha, R.M.; Franke, C.R.; Kasper, L.A.; Lima, A.P. 1985. The correlates of foraging mode in a community of Brazilian lizards. Herpetologica, 41: 324-332.

Magnusson, W.E. 1993. Body temperatures of field-active Amazonian savanna lizards. Journal of Herpetology, 27: 53-58.

Martín, J.; López, P. 1995. Influence of habitat structure on the escape tactics of the lizard Psammodromus algirus. Canadian Journal Zoology, 73: 129-132.

Martín, J.; López, P. 1999. Fleeing to unsafe refuges: effects of conspicuousness and refuge safety on the escape decisions of the lizard Psammodromus algirus. Canadian Journal Zoology, 78: 265-270.

Murcia, C. 1995. Edge effects in fragmented forest: implications for conservation. Trends in Ecology \& Evolution, 10: 1-5.

Pérez-Mellado, V. 1998. Podarcis lilfordi (Gunther,1874). In: Salvador, A. (Ed.). Fauna Iberica. Museo Nacional de Ciencias Naturales, Madrid, p.272-282.

Pianka, E.R.; Pianka, H.D. 1970. The ecology of Moloch horridus (Lacertilia: Agamidae) in Western Australia. Copeia, 1970: 90-103.

R Development Core Team. 2020. R: A language and environment for statistical computing. R Foundation for Statistical Computing. (http://r-project.org/). Acessed on 12 Aug 2020. 
Robinson, S.K. 1994. Habitat selection and foraging ecology of raptors in Amazonian Peru. Biotropica, 26: 443-458.

Rocha, C.F.D.; Bergallo, H.G. 1990. Thermal biology and flight distance of Tropidurus oreadicus (Sauria, Iguanidae) in an area of Amazonian Brazil. Ethology Ecology \& Evolution, 2: 263-268.

Salido, C.A.; Vicente, N.S. 2019. Sex and refuge distance influence escape decision in a Liolaemus lizard when it is approached by a terrestrial predator. Behaviour, 156: 909-925.

Samia, D.S.M.; Blumstein, D.T.; Stankowich, T.; Cooper, W.E. 2015. Fifty years of chasing lizards: new insights advance optimal escape theory. Biological Review, 91: 349-366.

Seebacher, F.; Shine, R. 2004. Evaluating thermoregulation in reptiles: the fallacy of the inappropriately applied method. Physiological and Biochemical Zoology, 77: 688-695.

Seebacher, F.; Franklin, C.E. 2005. Physiological mechanisms of thermoregulation in reptiles: a review. Journal of Comparative Physiology B, 175: 533-541.

Templeton, J.R. 1970. Reptiles. In: Whittow G.C. (Ed.). Comparative Physiology of Thermoregulation. Academic Press, New York, p.167-221.

Ventura, S.P.R.; Passos, D.C.; Machado, L.L.; Horta, G.; Galdino, C.A.B. 2016. Escape tactics by a neotropical montane lizard: a comparison of flight responses against natural and nonnatural predators. Acta Ethologica, 20: 9-15.

Vitt, L.J.; Caldwell, J.L. 2009. Herpetology: An Introductory Biology of Amphibians and Reptiles. 4th ed. Norman, Oklahoma. 757p.

Vitt, L.J.; Zani, P.A.; Barros, A.A.M. 1997. Ecological variation among populations of the gekkonid lizard Gonatodes humeralis in the Amazon Basin. Copeia, 1997: 32-43.

Vitt, L.; Magnusson, W.E.; Pires, T.C.A.; Lima, A.P. 2008. Guia de Lagartos da Reserva Adolpho Ducke - Amazônia Central, Editora INPA, Manaus, 175p.

Ydenberg, R.C.; Dill, L.M. 1986. The economics of fleeing from predators. Advances in the Study of Behavior, 16: 229-249.

Zamora-Camacho, F.J.; Rubiño-Hispán, M.V.; Reguera, S.; MorenoRueda, G. 2015. Thermal dependence of sprint performance in the lizard Psammodromus algirus along a 2200-meter elevational gradient: cold-habitat lizards do not perform better at low temperatures. Journal of Thermal Biology, 52: 90-96.

RECEIVED: $23 / 11 / 2019$

ACCEPTED: $12 / 08 / 2020$

ASSOCIATE EDITOR: Claudia Keller 